\title{
Agave atrovirens fibers as substrate and support for solid-state fermentation for cellulase production by Trichoderma asperellum
}

\author{
Naivy Y. Nava-Cruz ${ }^{1}$ Juan C. Contreras-Esquivel ${ }^{1} \cdot$ Miguel A. Aguilar-González $^{2}$ \\ Alberto Nuncio $^{1} \cdot$ Raúl Rodríguez-Herrera $^{1} \cdot$ Cristóbal N. Aguilar ${ }^{1}$
}

Received: 14 September 2015/ Accepted: 26 April 2016/Published online: 21 May 2016

(c) The Author(s) 2016. This article is published with open access at Springerlink.com

\begin{abstract}
Many efforts have been made to produce cellulase with better features and conditions, and filamentous fungi have played an important role in the bioprocess, growing in liquid and solid cultures with sugarcane bagasse, corn stover and others lignocellulosic materials. In the present study, Agave atrovirens fibers were partially characterized, thermal pretreated and used as support, substrate and inducer source for cellulolytic complex production by four strains of the genus Trichoderma, where $T$. asperellum was selected as the best option for this process after evaluating the enzyme activity and the invasion capacity on the pretreated Agave fibers. Fungi were able to grow on the Agave fibers secreting the complex cellulolytic enzyme. Results show Agave fibers as a good carbon source and support for T. asperellum for the production of the cellulolytic complex (endoglucanase 12,860.8 U/g; exoglucanase $3144.4 \mathrm{U} / \mathrm{g}$; and $\beta$-glucosidase $384.4 \mathrm{U} / \mathrm{g}$ ). These results show the promising potential this material could have in the production of the active enzyme cellulase complex.
\end{abstract}

Keywords Selection · Pretreatment · Biodegradation . Enzyme activity $\cdot$ Cellulase

Cristóbal N. Aguilar

cristobal.aguilar@uadec.edu.mx

1 Food Research Department, Faculty of Chemistry, Universidad Autónoma de Coahuila, 25280 Saltillo, Coahuila, Mexico

2 CINVESTAV-IPN, Unidad Saltillo, Ramos Arizpe, Coahuila, Mexico

\section{Introduction}

The Agave, a native plant of Mexico, grows in desert and semi-desert areas. In 2012 the sown area in Mexico was about 137,626.27 ha and 19,876.07 Ha only were harvested, which gives a production of $1,686,337.41 \mathrm{t}$ of Agave, with a price of 96 dollar/t (SIAP 2012). The main use of this crop is for beverages production, such as Tequila, Mezcal and Pulque, but this is only with some species like Tequiliana weber var azul and Angustifolia per example. A minority of these plants are used to make knitting yarns, paper and as limiting barrier in some areas; certain towns use the leaves to cook traditional Mexican dishes. As a result a large quantity of these plants have no use in the area. When the Agave flower appears it can reach $10 \mathrm{~m}$ high and after that the Agave plant dies, because this flower consumes all the disposable sugars present. So it is necessary to emphasize the importance in making use of the produced Agave crops that nowadays does not have a real use, though it could be used to obtain considerable amounts of fermentable sugars, oligosaccharides, composite and diverse materials, in addition to the alcoholic beverages.

To obtain many of these mentioned products, it is necessary to degrade the complex fibers of the Agave leaves.

The Agave cell wall composition is structured mainly by cellulose and hemicelluloses that can be hydrolyzed to simple sugars the action of fermentation. The third major component in the Agave cell wall is lignin, which has a negative effect in the hydrolysis of polysaccharides and is the main cause of the recalcitrance of the cell wall, that is the resistance of cell walls to be converted into fermentable sugars. The percentages of these three main components is variable between crops. For example, the cellulose percentage may vary from 65 to 85 between 
different species. The hemicellulose content could be from 3 up to $11 \%$ in some species. And the lignin can be present in different species from 7 up to $16 \%$ (Escamilla-Treviño 2012; Nava-Cruz et al. 2015).

Other important components of the cell wall in Agave plants, mainly in the leaves are the water-soluble carbohydrates, also called non-structural carbohydrates, which are released after thermal treatment. In some species, such as Agave tequiliana weber, these components can be present in $90 \%$ of the dry matter (Mancilla-Margalli and Lopez 2006). In this kind of carbohydrates, fructans is the main component of the polymers. There is also present in this complex wall, the non-structural sugars, but these in much lower levels decreasing from the base to the top.

One of the most promising ways is the use of cellulases, which have the capacity to hydrolyze such leaves, resulting in fermentable sugars that can be used in different ways. For that reason the production of a cellulase complex using friendly ways that does not compromise all the factors involved is necessary. Cellulose is a polymer of glucose bound by $\beta-1,4$ linkages. But not all the cellulose materials have the same chain length and the level of interaction between chains (Cowling 1975). In waste cellulose between 40 and $60 \%$ is cellulose, the rest are divided in hemicelluloses, lignins and other residual materials (Eveleight et al. 2009). The use of lignocellulosic materials for this objective is also increasing. These materials are cheap, abundant and renewable; all these features make the material appropriate to use as substrate in the fermentation process to produce cellulases (Maeda et al. 2011).

Nowadays, there is a crucial need to produce cellulases with better specifications and through natural materials and ways. Cellulases hold the third place worldwide in enzyme industry by dollar volume (Rani et al. 2010). This group of enzymes are formed by three single enzymes: endoglucanases, exoglucanases and $\beta$-glucosidases; the first ones hydrolyze the cellulose polymer exposing reductive and no reductive ends of the linear polymer of glucose, while the second ones attack these terminations to liberate cellobiose and cellooligosaccharides (Bansal et al. 2011; Deswal et al. 2011; Talebnia et al. 2010). The $\beta$-glucosidases (BGL) will join the cellobiose units to liberate finally the desired product, glucose (Sukuruman et al. 2009; Yah et al. 2010). Degradation process of cellulose consists of a six-step complicated process; the last one is a uniform catalysis process that includes participation of $\beta$-glucosidase on cellobiose (Chauve et al. 2010).

The interest in producing cellulases using new sources is increasing and new catalytic features are required. Several microorganisms capable of degrading the cellulosic material have been reported; actually there is a variety of studied microorganisms with special features such as aerobic and anaerobic bacteria (Gilkes et al. 1991;
Kumar et al. 2004; Thirumale et al. 2001) soft and white rot fungi (Chung-Yi et al. 2009; Lo et al. 2010; Shrestha et al. 2009; Tanaka et al. 2009) and anaerobic fungi (Dashtban et al. 2009; Ljungdahl 2008). In some cases the cellulases are secreted as free molecules, like the example of filamentous fungi, actinomycetes and aerobic bacteria. The most used microorganisms to produce these kinds of lignocellulosic enzymes are filamentous fungi such as Trichoderma, Fusarium, Phanerochaete, Penicillium, etc. (Bak et al. 2009; de Siqueira et al. 2010; Javed et al. 2007; Lo et al. 2010; Mathew et al. 2008). The aim of this study was to produce cellulases in solid-state fermentation using as unique carbon source, inducer and support, Agave atrovirens fibers, by the action of a strain of Trichoderma spp.

\section{Materials and methods}

\section{Fungal strains and materials}

A set of 4 strains of Trichoderma identified as Trichoderma harzianum (T1-04), Trichoderma asperellum (T2-31) and 2 different more only known as Trichoderma spp. codified as Trichoderma T2 and Trichoderma T2-11 were obtained from the micoteca of the Autonomous Agrarian University Antonio Narro, and the T2 were obtained from the micoteca of the Autonomous University of Coahuila, both in Saltillo Coahuila, Mexico. The strains were reactivated in PDA at $28{ }^{\circ} \mathrm{C}$ until they have enough spores to make a suspension with Tween 80 .

The Agave plant was collected also in the first University. Potato agar dextrose (PDA) was purchased in Sigma Aldrich as well as carboxymethyl cellulose (CMC), p-nitrophenyl, $\beta$-D-glucopyranoside (pNPG) and the compounds of the Mandels medium. Paper filter strips of $1 \times 5 \mathrm{~cm}$ (50 mg, Whatman \#1), citrate buffer $\mathrm{pH} 4.8$, $0.05 \mathrm{M}$ were also used in this study.

\section{Agave fiber characterization}

The fibers of Agave atrovirens were characterized as previously reported by (Medina et al. 2011) to measure the cellulose content by a gravimetric technique with the acid and neutral detergent fiber method (Van Soest et al. 1991) with two different types of fibers; the first one is a hydrothermal treatment and the second one a chemical treatment with $\mathrm{NaOH}$. In the hydrothermal treatment the fibers were peeled and sliced into small squares $(2 \times 2 \mathrm{~cm}$ approximately), then the pieces were autoclaved for $30 \mathrm{~min}$ to $120^{\circ} \mathrm{C}$. After that, the material was dehydrated in an oven to $70{ }^{\circ} \mathrm{C}$ for $48 \mathrm{~h}$. The reducing sugars present in the fibers were partially removed by multiple washing cycles 
with boiling water. The fibers were dried and then milled in a grinder (Mussatto et al. 2008; Flores-Maltos et al. 2014).

For the chemical treatment the fibers were peeled and sliced into small squares $(2 \times 2 \mathrm{~cm}$ approximately $)$ and dehydrated in an oven at $70{ }^{\circ} \mathrm{C}$ for $48 \mathrm{~h}$. The material was then milled in a grinder and placed in an $\mathrm{NaOH}$ solution ( $2 \%$ ) in a relation of 1:20. This was autoclaved by $30 \mathrm{~min}$ at $120{ }^{\circ} \mathrm{C}$. The material was washed, filtered and dehydrated at $70{ }^{\circ} \mathrm{C}$ (Medina et al. 2011).

The cellulose content was evaluated by a gravimetric technique (neutral detergent fiber method) using $0.5 \mathrm{~g}$ of the sample heated to boiling in $100 \mathrm{ml}$ of neutral detergent plus $50 \mu \mathrm{l}$ of heat stable amylase added before the beaker is placed on heat. At this point sodium sulfite is added $(0.5 \mathrm{~g})$. Then the sample is boiled for $1 \mathrm{~h}$ and filtered on sintered glass coarse crucible or Whatman 54 paper.

In the acid detergent fiber (ADF) the procedure was according to the AOAC. This procedure avoided the use of decalin. The Klason lignin procedure was developed at the same time.

For both kind of fibers were also measured the total and reducing sugars with citrate buffer $50 \mathrm{mM}$ at $\mathrm{pH} 4.8$ and $50{ }^{\circ} \mathrm{C}$ (Trevelyan and Harrison 1952; Miller 1959), respectively, and the $\mathrm{pH}$.

\section{Agave fibers pretreatment}

In this part were used the last two procedures described above (hydrothermal and chemical) to evaluate which one gives the best results in growing and enzyme activity, so hydrothermal and chemical procedures were evaluated for strains (T2-31, T1-04, T2-11 and T2). Radial growth and enzyme activity were evaluated to choose the best pretreatment of the fibers.

\section{Strain selection}

Kinetics were run for the four strains of Trichoderma (previously mentioned) to observe the radial growth and find which strain can adapt more easily to the Agave atrovirens fibers. The fermentations were realized in 6-cm-diameter petri dishes to observe the radial growth, using $3 \mathrm{~g}$ of dried fibers and adjusted to $80 \%$ humidity with the Mandels medium $\left(\mathrm{NH}_{4}\right)_{2} \mathrm{SO}_{4}(1.40), \mathrm{KH}_{2} \mathrm{PO}_{4}$ (2.03), $\mathrm{CaCl}_{2}$ (0.30), $\mathrm{MgSO}_{4} \cdot 7 \mathrm{H}_{2} \mathrm{O}$ (0.30), peptone (1.0), and a trace metals solution from $\mathrm{FeSO}_{4} \cdot 7 \mathrm{H}_{2} \mathrm{O}(0.005)$, $\mathrm{MnSO}_{4} \cdot 4 \mathrm{H}_{2} \mathrm{O} \quad(0.0016), \quad \mathrm{ZnSO}_{4} \cdot 7 \mathrm{H}_{2} \mathrm{O} \quad(0.0014)$, $\mathrm{CoCl} \cdot 6 \mathrm{H}_{2} \mathrm{O}$ (0.02), urea (0.3), yeast extract $(0.25)$, $\mathrm{CuSO}_{4} \cdot 5 \mathrm{H}_{2} \mathrm{O}$ (0.001) (in $\mathrm{g} / \mathrm{l}$ ), and for this stage, the dishes were inoculated with an explant $(1 \mathrm{~cm}$ diameter) of a previously reactivated strain for each of them. The kinetics were stopped when the first strain reached the limit of the Petri dish (84 h).
With respect to radial speed of growth, the distance reached after $12 \mathrm{~h}$ for each strain to the cardinal points (North, South, West, East) were measured and then the velocity per strain was calculated.

At the end of the fermentation (84 h) enzymatic activity for the three components of the complex (exoglucanase, endoglucanase and $\beta$-glucosidase) to the obtained extract was measured; protein and total sugars were also measured as is described below. Thereby, the best enzymatic activity titers and the radial growth were used as criteria for choosing the strain to be used in the fermentation.

\section{Growth analysis}

To observe the growth pattern presented by the selected strain of Trichoderma in the Agave fibers, and the adaptation level to the substrate and support, scanning electronic photomicrographs of the initial and final time $(84 \mathrm{~h})$ of the first fermentation for radial growth were taken. The samples were taken directly from the reactor, using $1 \mathrm{~g}$ of fibers in a thermo-balance at $110^{\circ} \mathrm{C}$ until the samples were dried. The samples were placed in aluminum slides and subjected to an environmental scanning electron microscope (Phillips XL30-ESEM) with low vacuum at $20 \mathrm{keV}$ (kilo electron volts) with a distance of $7.5 \mathrm{~mm}$ and a spot size of 4.5 .

\section{Time course of cellulase production in SSF}

The strain with best results in the previous stages was selected to realize a kinetic and observe the time with the best enzyme activity. The conditions for the fermentation were the same as used in the selection fermentation, and the fibers were also adjusted to $80 \%$ humidity with Mandels medium and incubated at $29{ }^{\circ} \mathrm{C}$ for $312 \mathrm{~h}$. An inoculum of the spore suspension obtained from a previous strain reactivation $\left(1 \times 10^{7}\right.$ per gram of fibers $)$ was added to the fibers. To collect the samples each $24 \mathrm{~h} 14$ plates (reactors) in triplicate were assembled.

\section{Cellulase production in SSF bioreactors}

The enzyme production was realized using $1 \mathrm{~kg}$ fermentation trays, and using as support and substrate Agave atrovirens fibers (200 g dry weight). The humidity was adjusted at $80 \%$ as before with Mandels medium. This reactors were performed three times corresponding to the highest enzyme activity points. An inoculum of the spore suspension $\left(1 \times 10^{7} / \mathrm{g}\right.$ of fibers $)$ was added in the medium, obtained from the previous reactivation ( 7 days), all this material was carefully homogenized and incubated at $29{ }^{\circ} \mathrm{C}$ for 216,240 and $312 \mathrm{~h}$ to obtain the best titers in each enzyme. 


\section{Crude extract recovery}

For the strain selection $20 \mathrm{ml}$ of citrate buffer $(\mathrm{pH} 4.8$, $0.05 \mathrm{M}$ ) was used for each tray and was carefully homogenized for $2 \mathrm{~min}$, and separated with a muslin cloth. Thereby the obtained extract was kept in congelation for further analysis. For obtaining the enzymatic extract, $1 \mathrm{~kg}$ of fermented mass from fermenter trays was put under manual pressure without any additional buffer. The fermented material was put in a muslin cloth and squeezed, the obtained liquid stored in congelation for further analysis.

\section{Analytical determinations}

\section{Exoglucanase activity}

Exoglucanase activity was analyzed according to the Roussos modification method (1985); Whatman filter No. 1 paper strips (substrate) were collocated in tubes with $1 \mathrm{ml}$ of the buffer and $1 \mathrm{ml}$ of the sample (reaction mix), it was incubated at $50{ }^{\circ} \mathrm{C}$ for $1 \mathrm{~h}$ in a thermo bath, and then reducing sugars were determined with Miller's method (1959). An enzyme blank and a substrate blank were used, the first one contained the substrate (1 strip) and the buffer $(1 \mathrm{ml})$, and the second one contained the enzymatic extract $(1 \mathrm{ml})$ and the buffer $(1 \mathrm{ml})$. To calculate the final absorbance, the blanks were added themselves and then subtracted from the reaction mix; after that formula (1) was used to calculate the international units of enzymatic activity. One enzyme activity unit was defined as the amount of enzyme that released $1 \mu \mathrm{mol}$ of glucose per minute under the assay conditions.

$\frac{U}{L}=\frac{g}{L} \times \frac{\text { vol rxn }}{\text { vol ext enz }} \times \frac{1 \mathrm{~mol}}{180 \frac{\mathrm{g}}{\mathrm{mol}}} \times \frac{1 \times 10^{6} \mu \mathrm{mol}}{1 \mathrm{~mol}} \times \frac{1}{\text { rxn time }}$

vol $=$ volume $; \quad$ rxn $=$ reaction $; \quad$ ext $=$ extract $; \quad$ enz $=$ enzyme.

\section{Endoglucanase activity}

This activity was performed using Roussos adaptation method (1985). It consists in a reaction mix of $1 \mathrm{ml}$ of CMC ( $1 \%$ in citrate buffer $\mathrm{pH} 4.8,0.05 \mathrm{M})$ and $1 \mathrm{ml}$ of the enzymatic extract. It was incubated in a thermo bath for $30 \mathrm{~min}$ at $50^{\circ} \mathrm{C}$, and after that reducing sugars were determined to the samples with Millers method. The international units of enzymatic activity were calculated by the same Eq. (1). This assay also used the enzyme and substrate blanks.
A qualitative analysis was also performed to prove endoglucanase activity, using CMC $(0.2 \%)$ in a citrate buffer $(0.05 \mathrm{M}, \mathrm{pH} 5)$ with agarose $(1 \%)$ in petri dishes. The extract $(50 \mu \mathrm{l})$ was placed in the middle of the solidified mixture and the reaction was maintained for $10 \mathrm{~min}$. After that, the plate was incubated at $37^{\circ} \mathrm{C}$ for $12 \mathrm{~h}$. The plate was washed with distilled water ten times, with 10-min rest between washings. The dish was covered with Congo red $(0.1 \%)$ and left for $1 \mathrm{~h}$, after that it was washed with $\mathrm{NaCl}(1 \mathrm{M})$ five times, giving $10 \mathrm{~min}$ between washing.

\section{$\beta$-Glucosidase activity}

This activity was determined by Vattem and Shetty method (2002). $100 \mu \mathrm{l}$ of p-NPG (9 Mm) was used as substrate, then $100 \mu \mathrm{l}$ of the crude extract with $800 \mu \mathrm{l}$ of the citrate buffer (0.05 M, pH 4.8) was added. Mix reaction, substrate and enzyme blanks were also used as previously. All assays were performed in triplicate.

\section{Quantitative enzyme assay}

A $0.2 \%$ carboxymethylcellulose (CMC) in citrate buffer $50 \mathrm{mM}$ with $\mathrm{pH} 5$ was prepared. Agarose $(1 \%)$ was added and placed in petri dishes to form a gel. $50 \mu \mathrm{l}$ extract fermentation were located in the middle of the plate and after $10 \mathrm{~min}$ were incubated at $37{ }^{\circ} \mathrm{C}$ for $12 \mathrm{~h}$ in humidity presence to avoid dehydration. The sample was washed with distilled water at intervals of $10 \mathrm{~min}$ between each washing. The sample was dyed with Congo red $(0.1 \%)$ and after $1 \mathrm{~h}$ the sample was washed with $\mathrm{NaCl} 1 \mathrm{M}$ to remove excess.

\section{Other analysis}

The extracts obtained from the fermentation were also analyzed for protein using the Bradford method (1976), and for total sugars using the Dimler method (Dimler 1952). All assays were performed in triplicate.

\section{Results}

\section{Agave fiber characterization}

Table 1 summarizes the results of the different analysis realized to the pretreated fibers. The content of cellulose found in the Agave atrovirens fibers was about $23.48 \%$ with hydrothermal treatment, and $67.12 \% \mathrm{w} / \mathrm{w}$ for the chemical treatment. The total sugars found in the hydrothermal one were 0.16 and $0.73 \mathrm{~g} / \mathrm{l}$ in the chemical one. The reducing sugars are 0.04 and $0.07 \mathrm{~g} / \mathrm{l}$ for 
Table 1 Partial characterization of the Agave atrovirens fibers

\begin{tabular}{lllll}
\hline Treatment & Cellulose $(\%)$ & Total sugars $(\mathrm{g} / \mathrm{l})$ & Reducing sugars $(\mathrm{g} / \mathrm{l})$ & $\mathrm{PH}$ \\
\hline Hydrothermal & 23.48 & 0.16 & 0.04 & 5.40 \\
Chemical & 67.12 & 0.73 & 0.07 & 6.56 \\
\hline
\end{tabular}

Table 2 Cellulase production in SSF bioreactors

\begin{tabular}{llc}
\hline Enzyme & Time $(\mathrm{h})$ & Enzymatic activity $(\mathrm{U} / \mathrm{g})$ \\
\hline Exoglucanase & 240 & $3144.4 \pm 87.4$ \\
Endoglucanase & 216 & $12,860.8 \pm 186.3$ \\
$\beta$-Glucosidase & 312 & $384.4 \pm 26.6$ \\
\hline
\end{tabular}

hydrothermal and chemical, respectively. The $\mathrm{pH}$ was 5.40 for the hydrothermal and 6.56 in the chemical one.

\section{Agave fibers pretreatment}

The chemical pretreatment did not have influence on the microbial growth in the fibers with any strain and in consequence the enzyme activity was not expressed. The hydrothermal pretreatment shows growth with the four strains, so for this reason, the selected pretreatment was the hydrothermal one. This pretreatment results in a bigger surface area for the enzymatic system induced for the carbon source through Trichoderma.

\section{Strain selection}

The radial growth for each strain was measured and the average in the growth rate obtained. Enzymatic activity was also tested. The results are given in Table 2 .

The growth rate did not represent a significant difference between strains, the four strains were able to grow in the fibers with similar speed, causing the excretion of cellulolytic enzymes by the strains.

The enzymatic activity presented by Trichoderma asperellum (T2-31) at $84 \mathrm{~h}$ was higher than the other strains, with $606.4 \mathrm{U} / \mathrm{g}$ of exoglucanase, $1213.2 \mathrm{U} / \mathrm{g}$ of endoglucanase and $582 \mathrm{U} / \mathrm{g}$ of $\beta$-glucosidase at $84 \mathrm{~h}$. These results are very high compared with the other three strains, which make a suitable strain to the next steps in the investigation. This shows its capacity to degrade the fibers in a better way for the secretion of enzymes with good cellulolytic activity.

\section{Growth analysis}

In Fig. 1a can be seen the Agave fibers without growth, while in Fig. 1b the Agave fibers appear wrapped by mycelium after $84 \mathrm{~h}$ of incubation under the conditions mentioned before. Only the images of Trichoderma asperellum T2-31 are shown in the agave fibers, since it was the strain with better features in growing and enzyme activity in comparison with the other three.

These micrographs demonstrate the capacity of Trichoderma to grow using the Agave fibers as substrate and support.

\section{Time course and cellulase production}

The fermentation with Trichoderma asperellum was maintained until $312 \mathrm{~h}$, and the sampled each $24 \mathrm{~h}$. The maximum activity was detected at $240 \mathrm{~h}$ for exoglucanase with $932 \mathrm{U} / \mathrm{g}$ (Fig. 2), while endoglucanase presented its maximum activity at $216 \mathrm{~h}$ giving as result $6116 \mathrm{U} / \mathrm{g}$ (Fig. 3), and finally the $\beta$-glucosidase presented at $312 \mathrm{~h}$ with $640 \mathrm{U} / \mathrm{g}$ (Fig. 4).

In Fig. 5 can be seen (part a) the blank of the assay that is completely red, and then the hydrolysis made by the enzymatic complex of Trichoderma asperellum (part b), where it is clear the hydrolysis halo marked by the discoloration of the Congo red dye.

\section{Cellulase production in SSF bioreactors}

Since the times of highest enzyme activity are known, the solid-state fermentation was performed in bigger reactors, using aluminum trays of $1 \mathrm{~kg}$. One tray for each of the enzymes was collocated and stopped at different times $(216,240$ and $312 \mathrm{~h})$. The tray of $216 \mathrm{~h}$ gave 12,860.8 U/g of endoglucanase, the fermentation stopped at $240 \mathrm{~h}$ showed $3144.4 \mathrm{U} / \mathrm{g}$ of exoglucanase and the fermentation at $312 \mathrm{~h}$ give $384.4 \mathrm{U} / \mathrm{g}$ of $\beta$-glucosidase (Table 2).

\section{Quantitative enzyme assay}

In Fig. 5 it can be seen in part (a) the blank of the sample were no extract cocktail fermentation was added, and all the carboxymethylcellulose plate are intact. In part (b) it can be seen how the extract fermentation cocktail acts in the carboxymethylcellulose degrading the surface, evidenced by the Congo red dye.

\section{Other analysis}

The total sugars quantified by the Dimler method were present in $67 \mathrm{~g} / 1$ at the beginning of the fermentation and at 

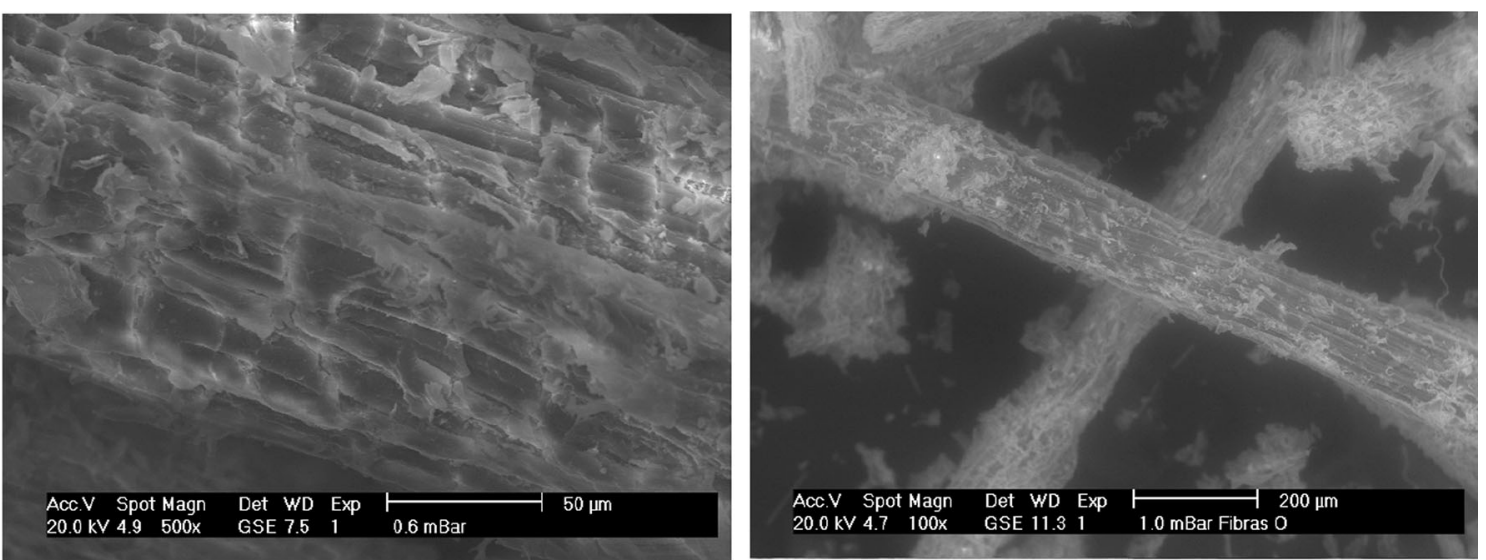

a Initial time of fermentation
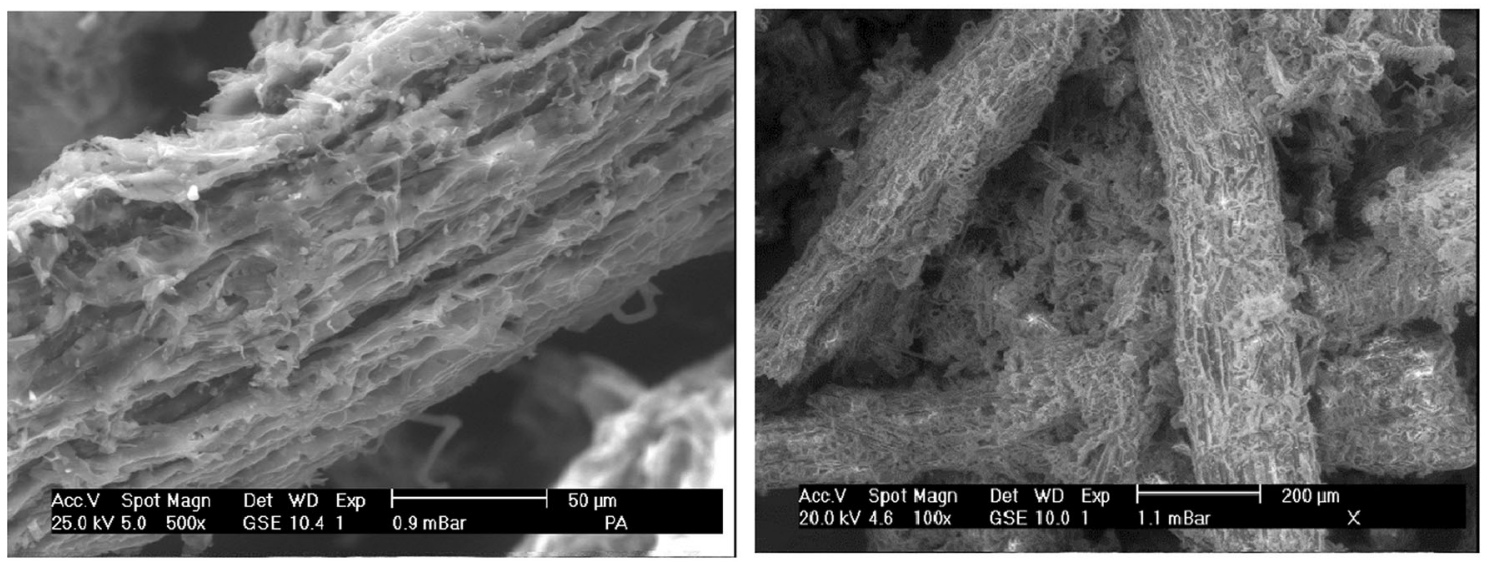

b Final time of fermentation

Fig. 1 Growth analysis of Trichoderma asperellum on Agave atrovirens fibers with a hydrothermal pretreatment

Fig. 2 Exoglucanase activity

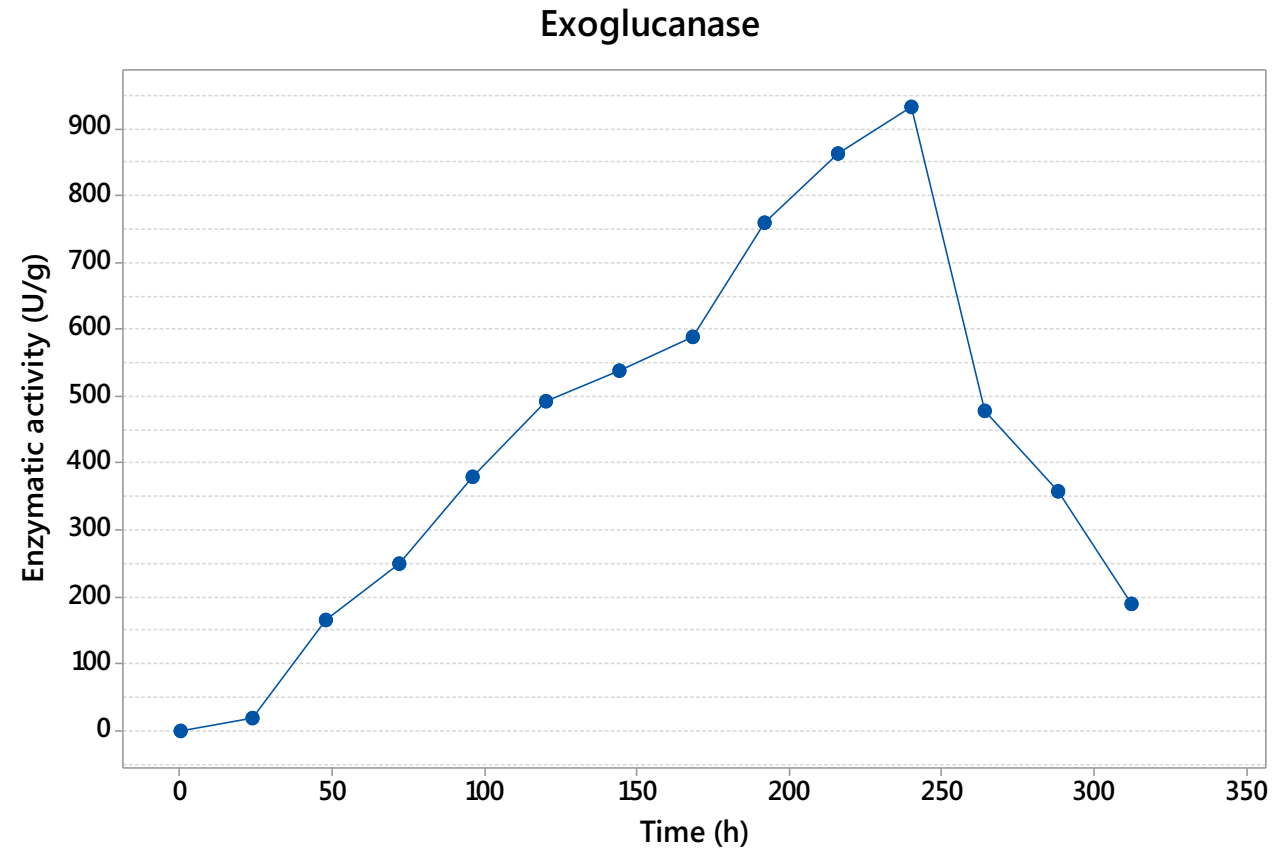


Fig. 3 Endoglucanase activity

\section{Endoglucanase}

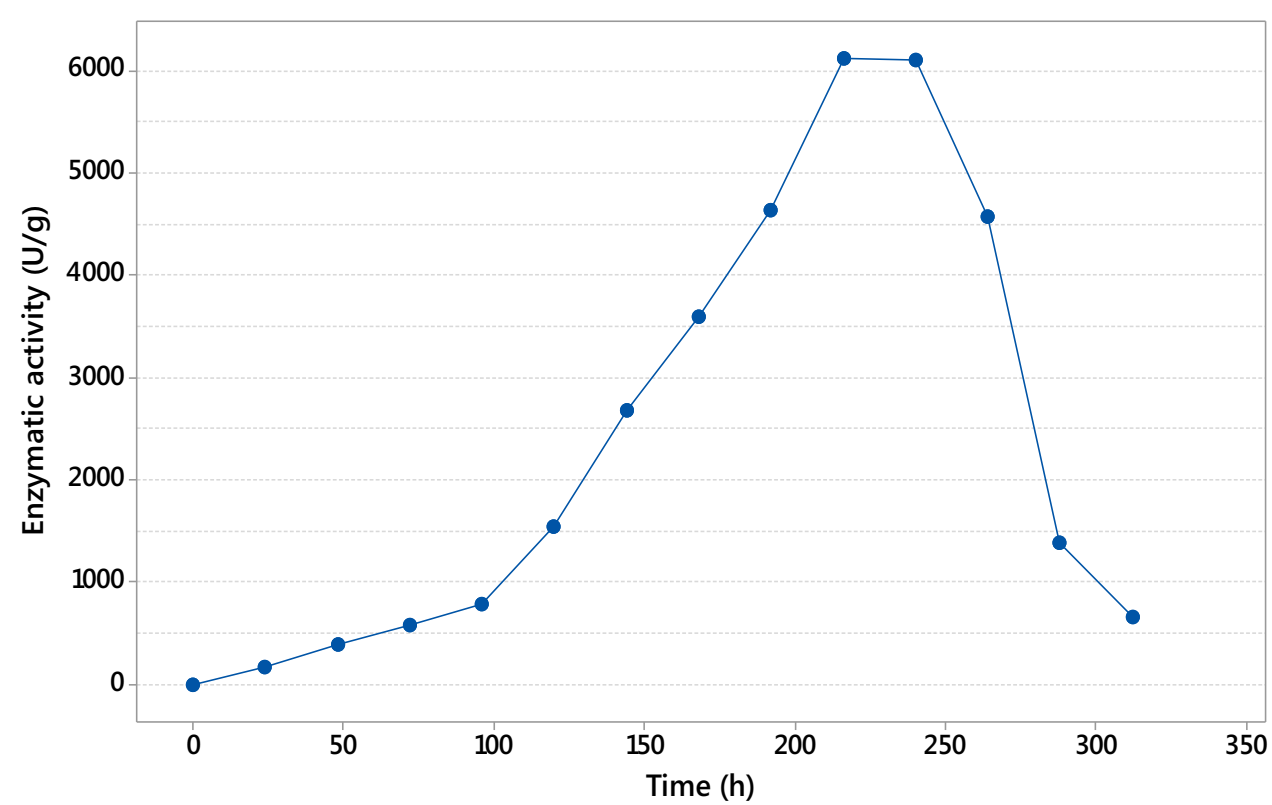

Fig. $4 \beta$-Glucosidase activity

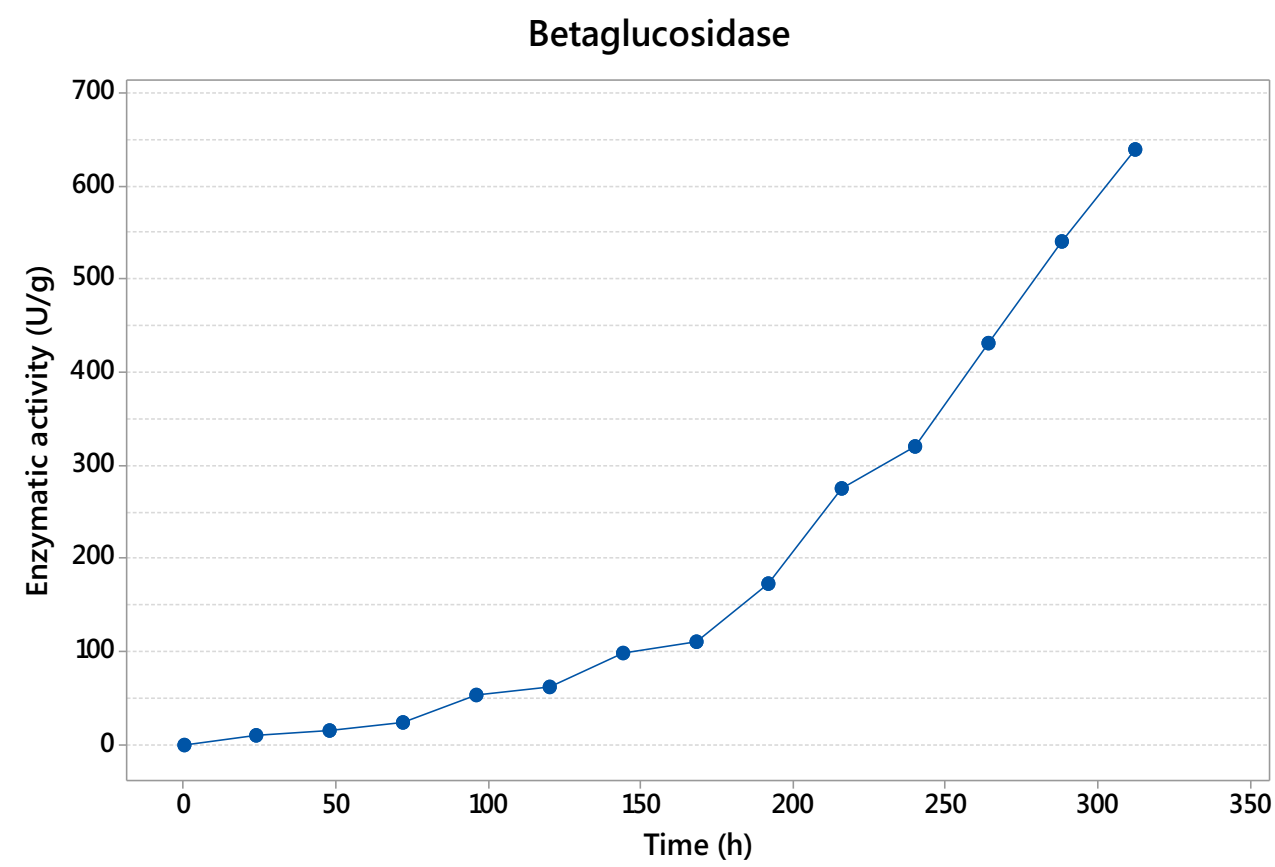

$312 \mathrm{~h}$ were only present with $18 \mathrm{~g} / \mathrm{l}$ (Fig. 6). These data show the sugar intake by Trichoderma, using up an average of $20 \mathrm{~g} / \mathrm{l}$ in the first $24 \mathrm{~h}$ and after this $4 \mathrm{~g} / \mathrm{l}$ per day. A slight increase in the total sugars present in the extract could be seen at $216 \mathrm{~h}$ with $9 \mathrm{~g} / \mathrm{l}$ more than the previous sampling followed by the consumption of $20 \mathrm{~g} / \mathrm{l}$ in the next $24 \mathrm{~h}$, and then another increase of $8 \mathrm{~g} / \mathrm{l}$ with a normal previous tendency of $4 \mathrm{~g} / \mathrm{l}$ each $24 \mathrm{~h}$.

The protein quantification (Fig. 7) shows that at $144 \mathrm{~h}$ of fermentation the maximum protein in the extract is present with $0.111 \mathrm{~g} / \mathrm{l}$, followed by a decrease until $0.058 \mathrm{~g} / \mathrm{l}$ at the end of the fermentation.

\section{Discussion}

The percentage of cellulose found is higher in the $\mathrm{NaOH}$ pretreated fibers and this should be for the removal of interfering compounds with the alkaline treatment, which expose widely the inside content (Medina et al. 2011). 

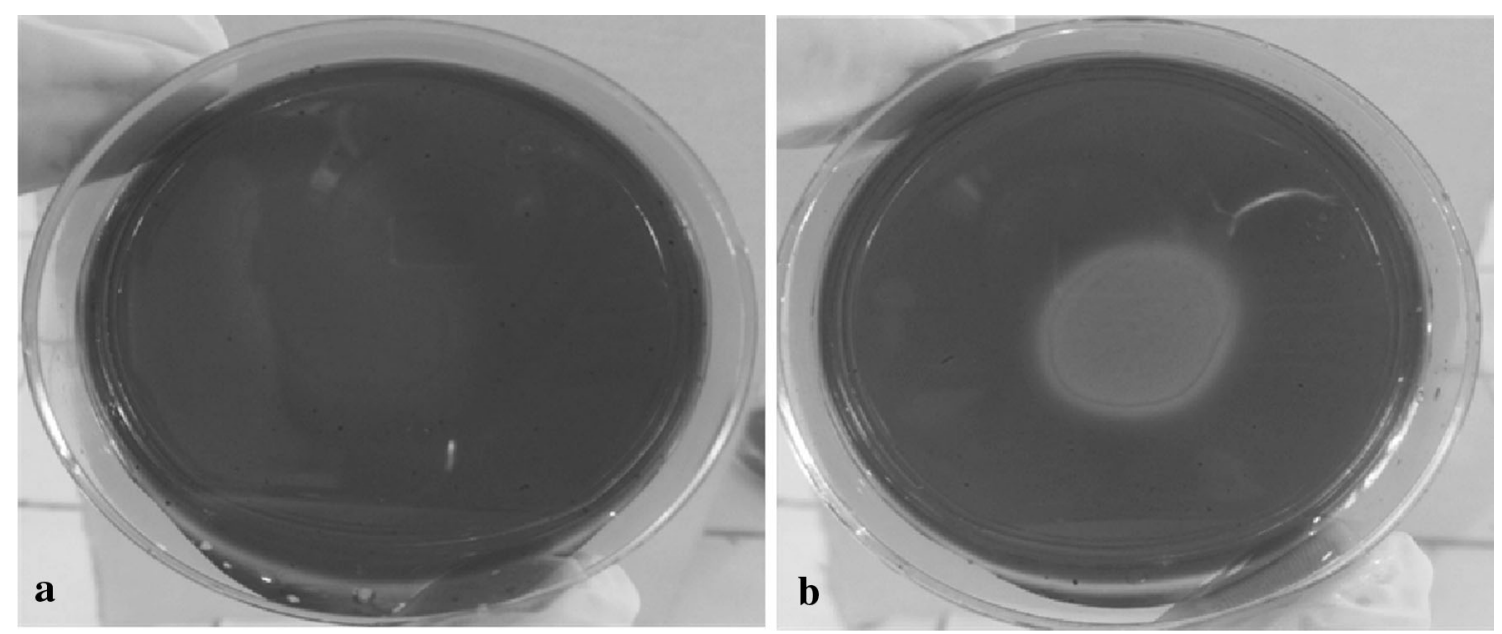

Fig. 5 Qualitative enzyme activity. Carboxymethylcellulose plate dyed with Congo red. a Blank (without fermentation extract). b Sample with fermentation extract in the surface

Fig. 6 Total sugars during fermentation with Trichoderma asperellum

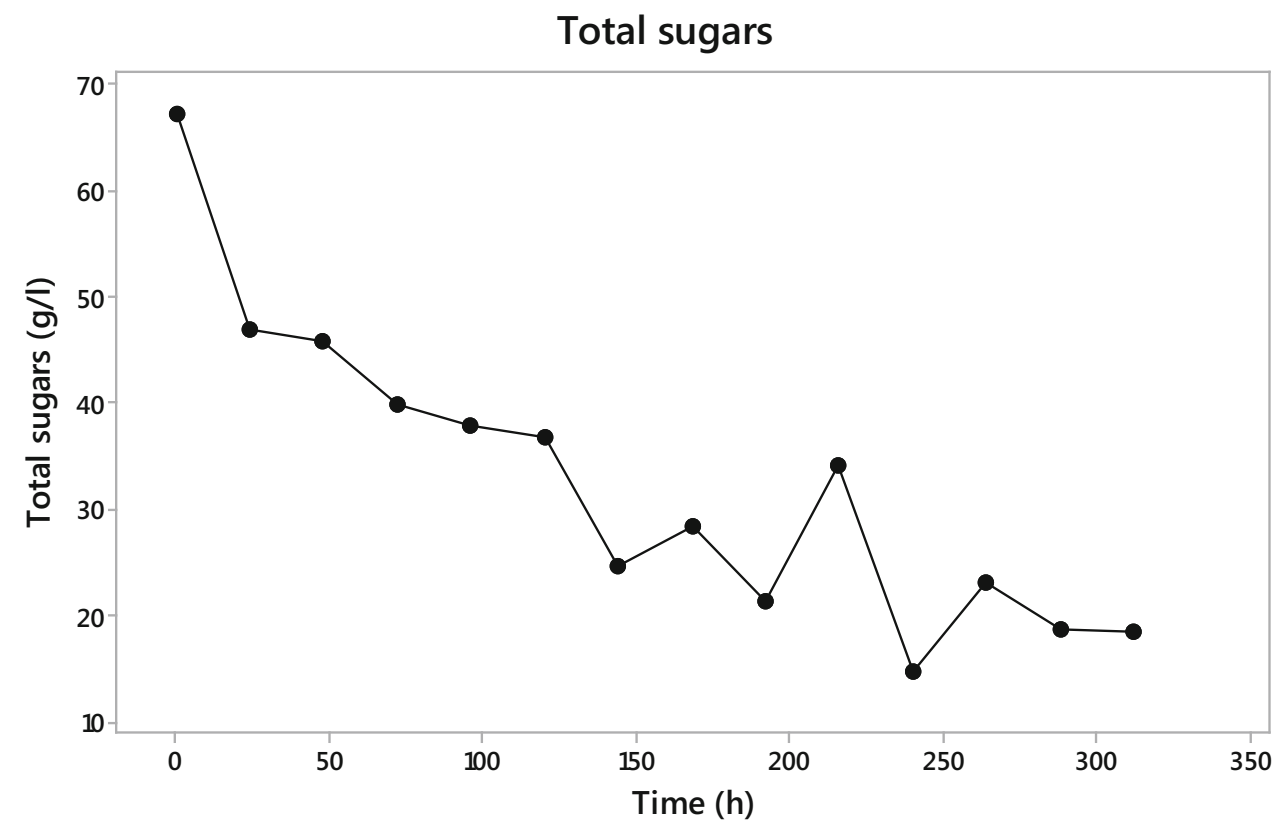

Martin et al. (2006) reported $57.9 \%$ w/w cellulose in Agave fourcroydes which is similar to that reported here, while Caspeta et al. (2014) reported $43 \%$ cellulose in Agave bagasse. The amount found is influenced by the used method.

In the characterization of the Agave fibers, the total and reducing sugars in the chemical treated fibers are higher than the hydrothermal ones, owing to the opening in the fibers structure that allows the release of more compounds, including carbohydrates as pentose (Hartree et al. 1987; Kumar et al. 2008).

The pretreatment selected to the fibers was the hydrothermal one due to the zero growth with the chemical one, probably caused by the formation and release of interferential compounds with the $\mathrm{NaOH}$ interaction with the fibers, as saponins, flavonoids ant others GücluÜstündag and Mazza (2007).

The hydrothermal pretreatment given to the fibers changes the crystalline unreactive form of the cellulose to an amorphous structure that facilitates the access to the cellulose material. This benefits the accessibility to the enzyme complex because of the disruption of the cellulose-hemicellulose-lignin structure and stirring compounds (Kumar et al. 2008).

In the strain selection analysis presented in Table 3, it can be seen the strain T2-31 with very high levels of 


\section{Protein}

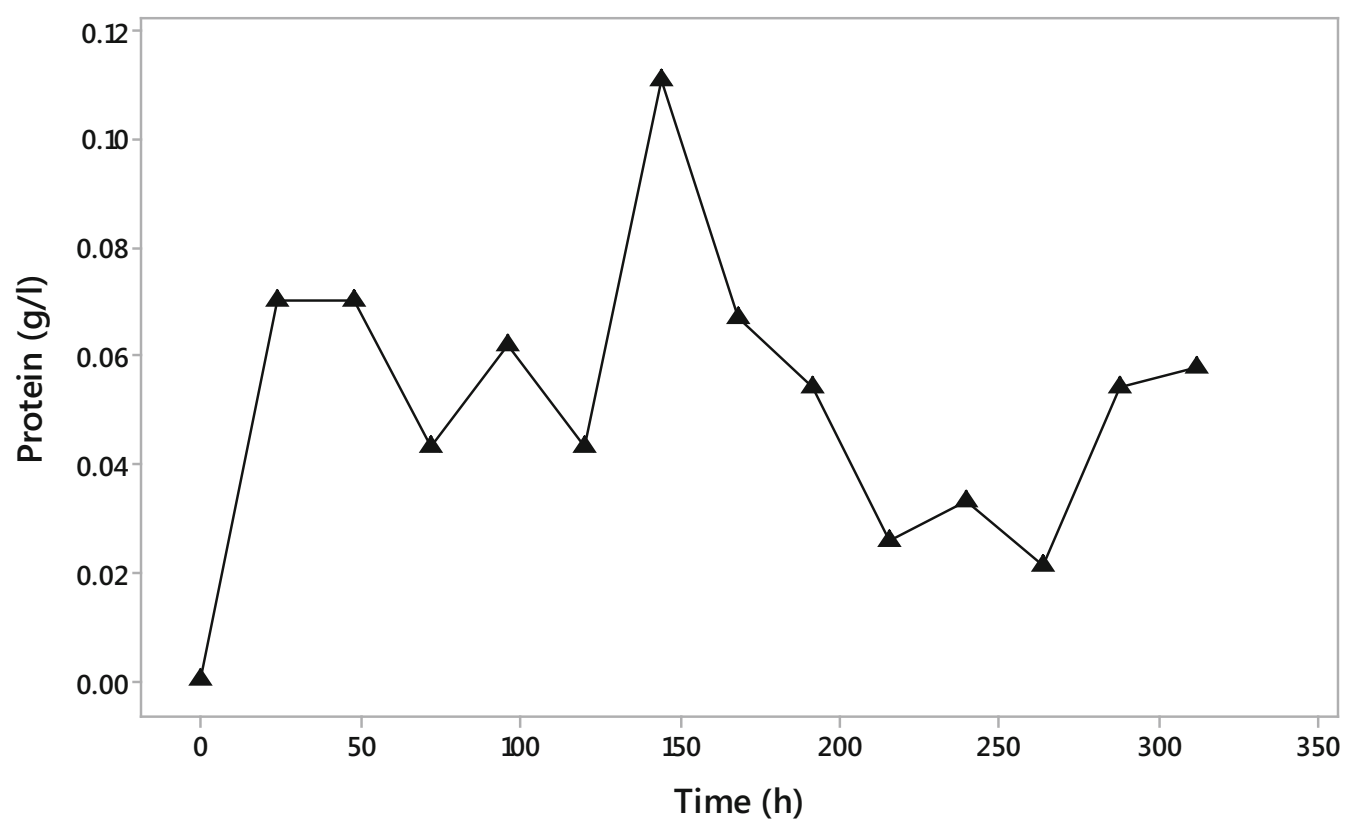

Fig. 7 Protein content in the fermentation with Trichoderma asperellum

Table 3 Growth velocity and enzyme activity for the strain selection

\begin{tabular}{lllcr}
\hline Strains & Growth rate $(\mathrm{cm} / \mathrm{h})$ & Exoglucanse $(\mathrm{U} / \mathrm{g})$ & Endoglucanase $(\mathrm{U} / \mathrm{g})$ & $\beta-\mathrm{Glucosidase}(\mathrm{U} / \mathrm{g})$ \\
\hline T2-31 & $0.038^{*}$ & 606.4 & 1213.2 & 582 \\
T1-04 & $0.04^{*}$ & 582.8 & 379.2 & 537.6 \\
T2-11 & $0.038^{*}$ & 340.4 & 254.4 & 157.2 \\
T2 & $0.032^{*}$ & 192.8 & 58 & 9.2 \\
\hline
\end{tabular}

* Data statistically similar

endoglucanase compared with the other three strains, the same result but not with such difference with the exoglucanase and $\beta$-glucosidase is shown. This could be probably explained because this specie presents a better adaptability to the agave fibers in order to a synergic enzyme release of the three components of the cellulolytic complex, which makes in set the best performance of this four strains of Thrichoderma. The suitable features of Trichoderma asperellum have been also reported in many biochemical processes because of its enhanced cellulose production and lower catabolite repression. Same features are observed in the present investigation (Raghuwanshi et al. 2014).

Units of $\beta$-D-glucopyranose bound by $\beta-(1 \rightarrow 4)$ glycosidic links result in the polysaccharide known as cellulose (Kumar et al. 2008). To hydrolyze this polymer, in the fermentation process, the action of three enzymes is necessary that in this study, Trichoderma asperellum has shown can produce. This complex is formed by exoglucanase, endoglucanase and $\beta$-glucosidase. The time where the three enzymes present the maximum activity corresponds with the common mechanism of the complex enzyme, where the first enzyme appearing is endoglucanase, producing nicks in the cellulose polymer and then the exoglucanase acts to release cellooligosaccharides and finally the $\beta$-glucosidase liberate the final product, glucose (Rani et al. 2010). Kellermann and Rentmesiter (2013) and Kumar et al. (2008) reported that in the hydrolysis of amorphous cellulose a ratio of $6: 2: 1$ is commonly seen between endoglucanases, exoglucanases and $\beta$-glucosidases, respectively.

The large period of hydrolysis and the prolonged time in the presence of the enzymes could be associated to various factors, one of them, could be a strong binding in the insoluble cellulose (Lan et al. 2013; Zhou et al. 2004). Other option associated to this phenomenon could be an important quantity of enzyme linked in that insoluble cellulose, Zhou et al. (2004) mentioned that, those cellulase adsorbed is similar to the present in the crude extract, and 
Table 4 Comparison of cellulase production by Trichoderma asperellum with other fungi under SSF

\begin{tabular}{|c|c|c|c|c|c|}
\hline Strain & Substrate & $\begin{array}{l}\text { Enzyme activity } \\
\text { (UI/g) } \\
\text { Exoglucanase }\end{array}$ & Endoglucanase & $\begin{array}{l}\beta- \\
\text { Glucosidase }\end{array}$ & References \\
\hline Trichoderma asperellum SR7 & Wheat bran & 2.2 & 13.1 & 9.2 & $\begin{array}{l}\text { Raghuwanshi et al. } \\
\text { (2014) }\end{array}$ \\
\hline $\begin{array}{l}\text { Trichoderma harzianum PPDDN10 NFCCI- } \\
2925\end{array}$ & Wheat bran & 0.74 & 4.10 & - & Pathak et al. (2014) \\
\hline Trichoderma reesei $\mathrm{RUT}-\mathrm{C} 30$ & Horticultural waste & 15.0 & 90.5 & 61.6 & Xin and Geng (2010) \\
\hline Aspergillus japonicus URM5620 & Castor bean meal & 953.4 & 191.6 & 88.3 & Nunes et al. (2011) \\
\hline Aspergillus niger FGSCA733 & $\begin{array}{l}\text { Jatropha curcas seed- } \\
\text { cake }\end{array}$ & 3974 & - & - & Ncube et al. (2012) \\
\hline Fomitopsis sp. RCK2010 & Wheat bran & 3.5 & 71.7 & 53.7 & Deswal et al. (2011) \\
\hline Trichoderma asperellum & $\begin{array}{l}\text { Agave atrovirens } \\
\text { fibers }\end{array}$ & 3144.4 & $12,860.8$ & 384.4 & Present work \\
\hline
\end{tabular}

also mentioned that cellulose can be calculated by the difference between the initial protein concentration and the final one. In this study, that cellulose adsorbed was calculated (data not shown) and demonstrate that the cellulose adsorbed, in each one of the three enzymes, was the same as the cellulose analytical calculated. It is important to mark that this work is not optimized and diverse physical and chemical factors such as $\mathrm{pH}$, temperature, adsorption, nitrogen, phosphorous, phenolic compounds and some inhibitors can improve or affect the bioconversion of the lignocellulosic material (Kumar et al. 2008).

Table 4 shows different species of fungi used with the same aim. Raghuwanshi et al. (2014) reported the use of a mutant strain of Trichoderma asperellum SR7 under optimized conditions in the degradation of wheat bran with titers of exoglucanase of 2.2, $13.2 \mathrm{IU} / \mathrm{g}$ of endoglucanase and $9.2 \mathrm{IU} / \mathrm{g}$ of $\beta$-glucosidase in periods ranging from 4 to 7 days. These results show the same specie strain but mutated, with titers well below the obtained in the present investigation, revealing the huge capacity of this strain Trichoderma asperellum to degrade a very difficult substrate as the Agave fibers. The big difference in the period time is important, but still that point, our results shows more than 1000 times more activity in the double of time. There are several species of fungi used for the same purpose, but each one with different production times, therefore a direct comparison is difficult.

The challenge in this cellulase production process is the maintenance of optimal conditions to the maximal enzyme production, which needs a balance between diverse factors to avoid the change from a productive state to a nonproductive, that in this case was not yet studied; however, the data shows the capacity of Trichoderma asperellum to degrade a complex matrix of cellulose, as Agave atrovirens fibers.

The analysis of total sugars suggest that the sugars produced by the saccharification of the Agave fibers, was constantly consumed by Trichoderma asperellum, which coincide with the time in the enzymes shown its maximum activity, allowing us bearing out that more than the sugars present in the extract, we can find some corresponding to the produced by the enzyme complex.

The tendency in the protein concentration is similar to that showed by the enzyme concentration, suggesting that the enzyme present in the extract was active.

Agave fibers of different species have been used to evaluate the effect of various factors present in the saccharification of Agave leaves using commercial cellulases or for the production of bioethanol (Li et al. 2014; Medina et al. 2011; Saucedo-Luna et al. 2011). Kalia and Vashistha (2012) reported the use of Brevibacillus parabrevis in the modification of the surface of Agave sisilana fibers for composite fabrication, and as a result bacterial cellulase treatment improves the features of the material such as thermal and crystallinity, as well as giving a smooth and shiny surface. But they do not report enzymatic titers, since the main objective was the scanning of the Agave fiber surface.

\section{Conclusions}

Trichoderma asperellum is able to grow using as carbon source and support the Agave atrovirens fibers pretreated with a hydrothermal process, releasing an enzymatic complex of cellulase made up by exoglucanase, endoglucanase and $\beta$-glucosidase, being the second most active in the degradation of the Agave fibers, resulting in promising fermentable sugars.

Acknowledgments We greatly thank the National Council of Science and Technology (CONACYT-Mexico) for the scholarship given to this investigation. And specially to each one of the authors and reviewers who contributed in this work. 


\section{Compliance with ethical standards}

Conflict of interest The authors report no conflict of interest. The authors alone are responsible for the content and writing of this article.

Open Access This article is distributed under the terms of the Creative Commons Attribution 4.0 International License (http:// creativecommons.org/licenses/by/4.0/), which permits unrestricted use, distribution, and reproduction in any medium, provided you give appropriate credit to the original author(s) and the source, provide a link to the Creative Commons license, and indicate if changes were made.

\section{References}

Bak JS, Ko JK, Choi I-G, Park Y-C, Seo J-H, Kim KH (2009) Fungal pretreatment of lignocellulose by Phanerochaete chrysosporium to produce ethanol from rice straw. Biotechnol Bioeng 104(3):471-482

Bansal N, Tewari R, Gupta JK, Soni SK, Soni R (2011) A novel strain of Aspergillus niger producing a cocktail of industrial depolymerizing enzymes for the production of second generation biofuels. Bio Res 6:552-569

Bradford M (1976) A rapid and sensitive method for the quantification of microgram quantities of protein utilizing the principle of protein-dye binding. Anal Biochem 72:248-254

Caspeta L, Caro-Bermúdez M, Ponce-Noyola T, Martínez A (2014) Enzymatic hydrolysis at high solids loadings for the conversion of the Agave bagasse to fuel ethanol. Appl energ 113:277-286

Chauve M, Mathis H, Huc D, Casanave D, Monot F, Lopes FN (2010) Comparative kinetic analysis of two fungal $\beta$-glucosidases. Biotechnol Biofuels 3:3. doi:10.1186/1754-6834-3-3

Chung-Yi W, Yi-Ru H, Ng C-C, Chan H, Lin H-T, Wen-Sheng T, Shyu YT (2009) Purification and characterization of a novel halostable cellulase from Salinivibrio sp. strain NTU-05. Enzyme Microb Technol 44(6-7):373-379

Cowling E (1975) Cellulose as a chemical and energy source. In: Wilke CR (ed) Biotechnology and bioengineering symposium, vol 5. Wiley-Interscience, New York, p 163

Dashtban M, Schraft H, Qin W (2009) Fungal bioconversion of lignocellulosic residues; opportunities and perspectives. Int $\mathrm{J}$ Biol Sci 5(6):578-595

de Siqueira FG, de Siqueira EG, Jaramillo PMD, Silveira MHL, Andreaus J, Couto FA, Batista LR, Filho EXF (2010) The potential of agro-industrial residues for production of holocellulase from filamentous fungi. Int Biodeter Biodegr 64(1):20-26

Deswal D, Khasa YP, Kuhad RC (2011) Optimization of cellulase production by a brown rot fungus Fomitopsis sp. RCK2010 under solid state fermentation. Bioresour Technol 102:6065-6072

Dimler RJ (1952) 1, 6-Anhydrohexofuranoses, a new class of hexosans. Adv Carbohydr Chem 7:37-52

Escamilla-Treviño LL (2012) Potential of plants from the genus Agave as bioenergy crops. Bioenerg Res 5:1-9

Eveleight DE, Mandels M, Andreotti R, Roche CH (2009) Measurement of saccharifying cellulose. Biotechnol Biofuels 2:21-26

Flores-Maltos D, Mussatto S, Esquivel J, Buenrostro J, Rodríguez R et al (2014) Typical Mexican agroindustrial residues as supports for solid-state fermentation. Am J Biol Sci 9:289-293

Gilkes NR, Henrissat B, Kilburn DG, Miller RC Jr, Warren RA (1991) Microbiol Rev 55:303-315

Güçlü-Üstündağ Ö, Mazza G (2007) Saponins: properties, applications and processing. Crit Rev Food Sci Nutr 47(3):231-258
Hartree MM, Yu EKC, Reid ID, Saddler JN (1987) Suitability of aspen wood biologically deligniWed with Pheblia tremellosus for fermentation of ethanol or butanol. Appl Microbiol Biotechnol 26:120-125

Javed MM, Khan TS, Haq I-U (2007) Sugar cane bagasse pretreatment: an attempt to enhance the production potential of cellulases by Humicola insolens TAS-13. Electron J Environ Agric Food Chem 6(8):2290-2296

Kalia S, Vashistha S (2012) Surface modification of Sisal fibers (Agave sisilana) using bacterial cellulase and methyl methacrylate. J Polym Environ 20:142-151

Kellermann SJ, Rentmesiter A (2013) Current developments in cellulase engineering. Chem Bio Eng Rev 1:6-13

Kumar B, Trivedi P, Mishra AK, Pandey A, Palni LMS (2004) Microbial diversity of soil from two hot springs in Uttaranchal, Himalaya. Microbiol Res 159(2):141-146

Kumar R, Singh S, Singh OV (2008) Bioconversion of lignocellulosic biomass: biochemical and molecular perspectives. Ind Microbiol Biotechnol 35:377-391

Lan TQ, Wei D, Yang ST, Liu X (2013) Enhanced cellulase production by Trichoderma viride in a rotating fibrous bed bioreactor. Bioresour Technol 133:175-182

Li H, Pattathil S, Foston M, Ding SH, Kumar R, Gao X, Mittal A, Yarbrough JM, Himmel M, Ragauskas A, Hahn M, Wyman C (2014) Agave proves to be a low recalcitrant lignocellulosic feedstock for biofuels production on semi arid lands. Biotechnol Biofuels 7:50

Ljungdahl LG (2008) The cellulase/hemicellulase system of the anaerobic fungus Orpinomyces $\mathrm{PC}-2$ and aspects of its applied use. Ann N Y Acad Sci 1125:308-321

Lo C-M, Zhang Q, Callow NV, Ju L-K (2010) Cellulase production by continuous culture of Trichoderma reesei Rut C30 using acid hydrolysate prepared to retain more oligosaccharides for induction. Bioresour Technol 101(2):717-723

Maeda NR, Serpa VI, Rocha VAL, Mesquita RAA, Santanna LMM, Castro AM, Driemeier CE, Pereira NJR, Polikarpor I (2011) Enzymatic hydrolysis of pretreated sugar cane bagasse using Penicillium funiculosum and Trichoderma harzianum cellulases. Process Biochem 46:1196-1201

Mancilla-Margalli NA, Lopez MG (2006) Water-soluble carbohydrates and fructan structure patterns from Agave and Dasylirion species. J Agric Food Chem 54:7832-7839

Martin C, Carrillo E, Torres M, Garcia L, Marcet M, Thomsen AB (2006) Determination of the chemical composition of tropical cellulosic materials by the detergent sequential system combined with acid hydrolysis. Cellul Cheme Technol 40:399-403

Mathew GM, Sukumaran RK, Singhania RR, Ashok P (2008) Progress in research on fungal cellulases for lignocellulose degradation. J Sci Ind Res 67(11):898-907

Medina M, Contreras-Esquivel J, De la Garza Toledo H, Rodriguez R, Aguilar N (2011) Enzymatic bioconversion of Agave leaves fiber hydrolysis using Plackett-Burman Design. Am J Agric Biol Sci 6:480-485

Miller GL (1959) Use of dinitrosalicylic acid reagent for determination of reducing sugar. Anal Chem 31(3):426-428

Mussatto S, Dragone G, Rodrigues L, Teixeira J (2008) Fructooligosaccharides production using immobilized cells of Aspergillus japonicas. In: Ferreira EC, Mota M (eds). Proceedings of the 10th International Chemical and Biological Engineering Conference-CHEMPOR 2008 Braga, Portugal, 4-6 Sep 2008

Nava-Cruz NY, Medina-Morales MA, Martinez JL, Rodriguez R, Aguilar CN (2015) Agave biotechnology: an overview. Crit Rev Biotechnol 35(4):546-559

Ncube T, Howard R, Abotsi E, Jansen van Rensburg E, Ncube I (2012) Jatropha curcas seed cake as substrate for production of 
xylanase and cellulase by Aspergillus niger FGSCA733 in solid state fermentation. Ind Crop Prod 37:118-123

Nunes P, Souza T, Aparecida K, Pinto G, Souza-Motta C, Porto A (2011) Cellulase production by Aspergillus japonicus URM5620 using waste from castor bean (Ricinius communis L.) under solid state fermentation. Appl Biochem Biotechnol 165:1057-1067

Pathak P, Kant N, Kumar A (2014) Production of crude cellulase and xylanase from Trichoderma harzianum PPDDN10 NFCCI-2925 and its application in photocopier waste paper recycling. Appl Biochem Biotechnol 172:3776-3797

Raghuwanshi S, Deswal D, Karp M, Kuhad R (2014) Bioprocessing of enhanced cellulase production from a mutant of Trichoderma asperellum RCK2011 and its application in hydrolysis of cellulose. Fuel 124:183-189

Rani RS, Sukumaran RK, Kumal AP, Larroche C, Pandey A (2010) Advancement and comparative profiles in the production technologies using solid state and submerged fermentation for microbial cellulases 46:541-549

Roussos S (1985) Croissance de Trichoderma harzianum par fermentation en milieu solide: Physiologie, sporulation et production de cellulases. Dissertation Thèse Doctorat d'Etat, Université de Provence, Marseille, France

Saucedo-Luna J, Castro-Montoya AJ, Martinez-Pacheco MM, SosaAguirre CR, Campos-Garcia J (2011) Efficient chemical and enzymatic saccharification of the lignocellulosic residue from Agave tequilana bagasse to produce ethanol by Pichia caribbica. J Ind Microbiol Biotechnol 38(6):725-732. doi:10.1007/s10295010-0853-Z

Shrestha P, Khanal SK, Pomettoiii AL, Van Leeuwen J (2009) Enzyme production by wood-rot and soft-rot fungi cultivated on corn fiber followed by simultaneous saccharification and fermentation. J Agric Food Chem 57(10):4156-4161

SIAP (2012) Servicio de Información Agroalimentaria y Pesquera 2012 Cierre de la Producción Agricola
Sukuruman RK, Singhania RR, Mathew GM, Pandey A (2009) Cellulase production using biomass feed stock and its application in lignocellulose saccharification for bio-ethanol production. Renew Energ 34:421-424. doi:10.1016/j.renene.2008.05.008

Talebnia F, Karakashev D, Angelikadi I (2010) Production of bioethanol from wheat straw: an overview on pretreatment, hydrolysis and fermentation. Bioresour Technol 101:4744-4753. doi:10.1016/j.biortech.2009.11.080

Tanaka H, Koike K, Itakura S, Enoki A (2009) Degradation of wood and enzyme production by Ceriporiopsis subvermispora. Enzyme Microb Technol 45:384-390

Thirumale S, Swaroopa Rani D, Nand K (2001) Control of cellulase formation by trehalose in Clostridium papyrosolvens CFR-703. Proc Biochem 37:241-245

Trevelyan WE, Harrison JS (1952) Studies on yeast metabolism. 1. Fractionation and microdetermination of cell carbohydrates. Biochem J 50(3):298-303

Van Soest PJ, Robertson JB, Lewis BA (1991) Methods for dietary fiber, neutral detergent fiber and non starch polysaccharides in relation to animal nutrition. J Dairy Sci 74:3583-3597

Vattem DA, Shetty K (2002) Solid-state production of phenolic antioxidants from cranberry pomace by Rhizopus oligosporus. Food Biotechnol 16(3): 189-210

Xin F, Geng A (2010) Horticultural waste as the substrate for cellulase and hemicellulase production by Trichoderma reesei under solid state fermentation. Appl Biochem Biotechnol 162:295-306

Yah CS, Iyuke SE, Unuabonah EI, Pillay O, Vishanta C, Tessa SM (2010) Temperature optimization for bioethanol production from corn cobs using mixed yeast strains. OnLine J Biol Sci 10:103-108. doi:10.3844/ojbsci.2010.103.108

Zhou LM, Yeung KW, Yuen CWM, Zhou X (2004) Characterization of ramie yarn treated with sodium hydroxide and crosslinked by 1, 2, 3, 4-butanetetracarboxylic acid. J Appl Polym Sci 91(3):1857-1864 